\title{
The Use of Image Media to Increase Learning Motivation in the Field of Social Sciences in Elementary School Students
}

\author{
S Ratnaningsih \\ \{sita@uinjkt.ac.id \} \\ State Islamic University (UIN) Syarif Hidayatullah Jakarta, Indonesia
}

\begin{abstract}
The low motivation to learn in class IV students in primary schools is a problem that is quite heavy felt by the teachers who teach in class. That's because children in grade 1 in primary school still don't know the learning objectives that are in school. This is supported by the learning system provided by the teacher, which is still largely unattractive, which causes students to be less enthusiastic in following the lessons. This research was conducted with the aim of increasing the motivation to learn elementary school students in class I by using media images. The research method used is Action research. The results showed that the use of image media in the activities of the teacher in the first cycle was $75.11 \%$ while in the second cycle was $86.81 \%$. These results indicate that an increase in teacher activity in an effort to increase student motivation and student activity. On the results of student learning motivation there was an increase from cycle I obtained $72.15 \%$ to $85.24 \%$ in the second cycle. This means an increase in the average motivation of students to increase by $16.89 \%$. From the results of this study it can be concluded that the application of learning using picture media can increase student motivation in Social Sciences in Primary Schools.
\end{abstract}

Keywords: Image Media, Learning Motivation, Social Sciences Learning, Elementary School Students.

\section{INTRODUCTION}

Social studies learning seeks to help students in solving problems faced, so as to make students increasingly understand and understand the social environment of their community. Social studies are taught in primary schools, intended so that students become good human beings and citizens, as expected by themselves, parents, society, and religion. Based on the understanding and purpose of social studies at the elementary school level as described above, it seems that a learning pattern is needed that can bridge the achievement of these goals. So that the ability and skills of teachers in choosing and using various models, methods, and learning strategies are constantly being improved so that social studies learning in elementary schools is really able to condition the effort to equip basic abilities and skills for students to become human beings and good citizens. However, in reality there are many students in elementary school who are very difficult in understanding social studies lessons, because in delivering their material, there are still many teachers in primary school who are less interesting, very monotonous and 
tend to be boring. For this reason, an effort is needed to be able to turn students in primary schools into enthusiasm and have high motivation to study social studies so as to improve learning outcomes in the social studies field. In this study, researchers tried to use image media, so students in elementary school in studying social studies can be excited in participating in social studies lessons delivered by their teacher.

Implementation of Social Sciences Learning in primary schools implemented in Indonesia, basically there are some components that need to be discussed first, such as methods, assessments, media, learning steps and the role of the teacher. After that, the steps to compile the Learning of Social Sciences and the Syllabus and Learning Plan will be discussed.

As a teacher, of course, know more about the conditions faced in the classroom, teachers often find students who are passive when learning Social Sciences. This is due to the lack of teacher presenting social science learning material that is more interesting, creative, and meaningful. In addition, the learning media used must be able to provide a pleasant experience and meet the needs to increase student motivation. Therefore, in the process of learning in the field of Social Sciences, educators should be able to present effective and efficient learning according to the mindset of students by applying various uses of the media and guiding students to develop their learning motivation. One of the simple visual media that can simplify the way students learn is drawing media. This media can be made, is not too expensive, and is easily understood and understood by students. Images can provide ideas or provide clarity about things. By using the picture media students are easier to understand learning. Based on some of the results of previous studies, image media can increase student motivation. Kasmaienezhadfard's research findings (2015)[1], show that images in textbooks can increase student creativity. The use of images for educational and learning purposes is vital, but textbook designers must be aware of the use of images. In this Kasmaienezhadfard research aimed at helping curriculum planners and designers to discuss the strengths of textbooks that will be strengthened by pictures and convey their weaknesses to convey to students. Research and Development (R\&D) and ADDIE Learning System Design (ISD) are used to develop media in Musnar research (2017)[2], on the process and results of developing comic-based learning media on Social-History Science subjects for fifth grade elementary schools. In conclusion, the research findings show that the comic-image based learning media developed are declared valid and can be used in contexts intended for Class Five Elementary Schools. Elpis Research (2017)[3] in class VI Elementary School shows that through the use of image media, social science learning outcomes can improve.

\section{RESEARCH METHOD}

This This research uses classroom action research methods or Classroom Action Research, namely research conducted in class with the aim of improving or improving the quality of learning practices. Bogdan, Robert C . Biklen. Sari Knopp in (Kasinah, 2013)[4], defines classroom action research as research carried out by educational practitioners with the aim of improving their professional practice and understanding students better. Accordingly, Taggart (1988)[5] state that, classroom action research is a center of research conducted in class, and only tries to investigate what actually happens to students in the class. This study focuses on social studies on Theme 1 in class IV Al-Fath Cirendeu Elementary School, totaling 33 students consisting of 12 male students and 21 female students, with the learning process using drawing media. 


\section{RESULTS AND DISCUSSION}

Data analysis in the discussion of the results of this study is based on observations made by researchers who have observed the activities of teachers in using media images in an effort to increase student motivation in thematic learning when the teaching and learning process takes place. The results of the analysis of teacher activity data and student participation in cycle I and cycle II are as follows:

The results of the acquisition of teaching activities of teachers in applying media images / photos are in quite good category. The percentage of teacher activity in the Social Science learning process using picture media in the first cycle obtained an average of $75.11 \%$ and is in the good category. As for the second cycle the results of the acquisition of teaching activities of teachers in applying the media image has increased which is in the category of very good. In the second cycle of the percentage of the teacher activity in the Social Sciences learning process using picture / photo media obtained an average of 86.81 and are in the very good category. These results can be concluded that in the first cycle of student learning activities in learning Social Sciences by using media images that have been implemented well.

The observations of the activities of the first cycle of the teacher can be concluded that the use of picture / photo media is going well. The results of the percentage of the first cycle of meetings 1 to 3 obtained an average motivation of students 72.15 and are in the good category. Based on the observations of the activities of the second cycle teachers, it can be concluded that the use of image media is going very well. The results of the percentage of the second cycle of meetings 1 and 3 obtained an average student participation of $86.25 \%$ and are in the very good category. These results can be concluded that in the second cycle of student learning activities in learning Social Sciences by using media images that have been implemented very well.The recap of observations of teacher activities in the use of image media and observations of students' learning motivation in Social Sciences learning cycle I and cycle II are shown in the following tables and diagrams:

Table I. Observation Results Learning Process and observation of student motivation:

\begin{tabular}{|c|c|c|c|}
\hline Number & Result of Learning Process & $\begin{array}{l}\text { Cycle I } \\
(\%)\end{array}$ & $\begin{array}{l}\text { Cycle II } \\
(\%)\end{array}$ \\
\hline 1. & Observation Activities & $75,11 \%$ & $86,81 \%$ \\
\hline 2. & $\begin{array}{l}\text { Observation Activities } \\
\text { Learning results }\end{array}$ & $72,22 \%$ & $85,24 \%$ \\
\hline Average & & $73,67 \%$ & $86,03 \%$ \\
\hline
\end{tabular}

Data analysis of observations of teacher activity in the first cycle obtained $75.11 \%$ while in the second cycle obtained $86.81 \%$. Increase in teacher activity in an effort to increase student motivation and their activity, which shows student motivation to increase by $16.75 \%$. The results of students' motivation in the first cycle obtained $72.22 \%$ to $85.24 \%$ in the second cycle. This means that the increase in the average student motivation increases by $15.09 \%$.

Basically, in a learning process carried out by a teacher and students, there is a relationship between student motivation and learning outcomes. Some authors, among them according to P. 
Pintrich (1999)[6] and S. Kang (2008)[7], the two experts stated that learning arises from the interaction between cognitive variables and the level of learning motivation possessed by students. Motivational variables have been widely studied by educational theories. These studies have found that students' intrinsic and extrinsic motivation have a high impact on the learning process. Extrinsic motivation according to C. Walker, A. Barbara and A. Robert (2000)[8] refers to motivation produced by external factors that surround students and affect students. Some theories about student motivation presented by A. Bandura (1997)[9], the experts emphasized that learning motivation is influenced by the factors of student expectations, the value obtained and the influence that makes student motivation to increase or decrease. Expectation refers to students' beliefs about what they want to achieve by doing certain tasks. Values affect the reasons why students become passionate about learning, doing certain academic tasks and their final learning outcomes. The influence that makes motivation to learn can be influenced by various factors, one of which is the use of image media as was done in this study.

In addition to media images, to improve student learning motivation is also done by using video, such as research conducted by Edna Bravo, et.all from the Department of Management Technical University of Catalonia, entitled: "Video as a New Teaching Tool to Increase Student Motivation" . In the study stated that this study based on the use of several video streams created as supporting material for learning and is used by 12 teachers with 487 students in the Terrassa Aeronautics and Industrial School (ETSEIAT). In this innovative way, it can be concluded that the learning tools with the help of video media have a tremendous impact on students' enthusiasm for learning, so that their learning achievements increase significantly after applying learning with the help of these media, which is applied in class.

Another article about increasing learning motivation is to utilize Information and Communication Technology (ICT) at school. Review the article with the title: "Effective use of ICT for Education and Learning by Drawing on Worldwide Knowledge, Research, and Experience: ICT as a Change Agent for Education", written by Syed Noor-Ul-Amir from the Department of Education, University Of Kashmir stated that information and communication technology (ICT) has become a common entity in all aspects of life.

Education is a very socially oriented activity and quality education is very much related to professional teachers in educating students. The findings of Yusuf (2005)[10], state that the use of Information and Communication Technology in education is very suitable for studentcentered learning. But with the world moving fast to digital media and information, the role of ICT in education is becoming increasingly important and will continue to grow and develop in the 21st century. The results of learning media research in the social sciences are carried out by Yanuari (2019)[11], The research results show that learning with Powtoon-based video media is very effective in improving learning outcomes in the field of social science in elementary schools. The results of the study (Heafner, 2014)[9] suggest that the use of technology in social studies as a means to motivate students by involving students in the learning process by using familiar teaching tools that increase the efficacy and self-esteem of students. Research from Ming Hung Lin (2017)[7], designing teaching activities for digital learning and applying technology tools flexibly. In this study, students were tested and continued the questionnaire survey to understand opinions about digital learning. The results of his research show that using digital learning can increase motivation and student learning outcomes. The results of this study indicate from Dwi Y (2018)[12], showing that: elementary school teachers have used learning media, such as books, pictures, tangible objects, and the environment, but teachers and students need to add interactive game-based multimedia to support learning activities in schools higher quality basis [13]. 


\section{CONCLUSIONS}

Based on the acquisition of classroom action research results that have been carried out for two cycles consisting of 6 meetings. Regarding the use of media images in learning Social Sciences class I Al-Fath Cirendeu Elementary School. Showing an increase in student motivation. These results can be seen in the analysis of the activity data of the first cycle teacher 1 at $73.75 \%$, meeting 2 at $75 \%$, meeting 3 at 75\%. So it can be concluded that the average acquisition of teacher teaching activity data for students in the first cycle was $74.58 \%$. In cycle II, the acquisition of data analysis results at meeting 1 was $86.25 \%$, meeting 2 was $90 \%$, and meeting 3 was $92.5 \%$. Then it can be concluded that the average acquisition of data in the second cycle is $89.58 \%$.

In the analysis of data from the activities of students in cycle I meeting 1 amounted to $73.75 \%$, cycle I meeting 2 amounted to $71 \%$, and cycle I meeting 3 amounted to $76 \%$, it can be concluded that the average acquisition of data on student activity cycle I 73, 75\% . In cycle II, the acquisition of data analysis results at meeting 1 was $78.75 \%$, meeting 2 was $89 \%$, and meeting 3 was $91 \%$. Then it can be concluded that the average acquisition of data from student activities in the second cycle is $86.25 \%$. The use of image media used in the learning process is to support the Social Science learning process that is provided to students at the elementary school level in the low grades.

\section{REFERENCES}

[1] S. Kasmaienezhadfard, M. Pourrajab, and M. Rabbani, "Effects of Pictures in Textbooks on Students' Creativity," Multi Discip. Edu Glob. Quest, vol. 2, no. 14, pp. 83-96, 2015.

[2] M. I. Daulay, "Developing Social Science-History’s Comics- Based Learning Media for the Fifth Grade of Primary School In Pekanbaru City," Int. J. Res. Couns. Educ., vol. 1, no. 1, p. 15, 2018.

[3] Elpis, Jurnal Primary Program Studi Pendidikan Guru Sekolah Dasar Fakultas Keguruan dan Ilmu Pendidikan Universitas Riau | Volume 6 | Nomor 2 | Oktober 2017 | ISSN: 2303-1514 |

[4] S. Kasinah, "Classroom Action Research," Pionir, vol. 1, no. 1, pp. 107-114, 2013.

[5] R. Mctaggart, The Action Research , Instructional Research Journal, pp. 1-12, 1997.

[6] P. R. Pintrich and E. V. De Groot, "Motivational and Self-Regulated Learning Components of Classroom Academic Performance," J. Educ. Psychol., vol. 82, no. 1, pp. 33-40, 1990.

[7] M. H. Lin, H. C. Chen, and K. S. Liu, "A study of the effects of digital learning on learning motivation and learning outcome," Eurasia J. Math. Sci. Technol. Educ., vol. 13, no. 7, pp. 3553-3564, 2017.

[8] C. O. Walker, B. A. Greene, and R. A. Mansell, "Identification with academics, intrinsic/extrinsic motivation, and self-efficacy as predictors of cognitive engagement," Learn. Individ. Differ., vol. 16, no. 1, pp. 1-12, 2006.

[9] T. Heafner, "Using technology to motivate students to learn social studies," Contemp. Issues Technol. Teach., vol. 4, no. 1, pp. 42-53, 2004.

[10] M. O. Yusuf, "Information and communication technology and education: Analysing the Nigerian national policy for information technology," Int. Educ. J., vol. 6, no. 3, pp. 316-321, 2005.

[11] Y. D. Puspitarini, M. Akhyar, and . D., "Development of Video Media Based on 
Powtoon in Social Sciences,” Int. J. Educ. Res. Rev., pp. 198-205, 2019.

[12] D. Y. Saputri, R. Rukayah, And M. Indriayu, "Need Assessment of Interactive Multimedia Based on Game in Elementary School: A Challenge into Learning in 21st Century," Int. J. Educ. Res. Rev., vol. 3, no. 3, pp. 1-8, 2018.

[13] K. Saddhono and M. Rohmadi, "A Sociolinguistics Study on the Use of the Javanese Language in the Learning Process in Primary Schools in Surakarta, Central Java, Indonesia." Int. Edu. Stu., vol. 7 no.6 pp 25-30, 2014 